\title{
SOCIALIZATION OF THE NEW METHOD FOR USE OF TOFU AUTOMATIC PRESS TOOL TO THE SME COMMUNITY
}

\author{
Dedik Romahadi, Hadi Pranoto, Alief A. Luthfie \\ Universitas Mercu Buana Jakarta, Indonesia.
}

\begin{abstract}
Based on observations, tofu home industry in several places in the city of Jakarta still uses conventional production methods. The printing and press process using conventional methods takes a long time the equipment used to print and press tofu is teak. According to home industry owners know to press 100 tofu in one container takes about 20 minutes. The process of producing tofu with a conventional system is less effective and efficient because it requires a long period of time. Based on these problems, the aim of this project is to socialize the new method of using the Automatic Tofu Press Tool so that it is useful in providing knowledge to the SME (Small Medium Enterprise) tofu community about more efficient and shorter press processes, and produces uniform production of both the texture and thickness of tofu produced.
\end{abstract}

Keywords: Tofu Automatic Press, Home Industry, SME.

\section{INTRODUCTION}

Mentioning typical foods of the country certainly will not be separated from tofu. Tofu is a processed product from soybeans that we often encounter on the market. Tofu has become a very popular food and is known by almost all Indonesian people. In addition to its populist price, the taste of tofu is very good, making many people do not mind consuming it with a fairly high frequency. Fortunately, behind the populace of tofu, it turns out there are so many nutrients from the content of tofu that this food offers so that if we consume it can get many benefits that are good for the body. Tofu is made from soybeans which are widely known for their rich protein content. In addition, the nutritional content of tofu and tempeh also has a lot of good fat and calories (Holle \& Dewi, 2014). We can also find vitamin B complex, magnesium, iron, calcium, zinc, and phosphorus in these foods. What's interesting about tofu is that everyone can consume it. In fact, vegetarians are not hesitant to consume it, given the high content of tofu tempeh in it.

Tofu also has very high isoflavones. Isoflavones are antioxidants that are good for protecting the body from various body health problems. In addition, many health experts say that consuming tofu can significantly reduce the risk of heart disease and osteoporosis problems. Consuming tofu as a substitute for animal food will make cholesterol and saturated fat in the body decrease by 10-20 percent significantly so that the risk of coronary heart disease decreases. In addition, many studies have shown that if a diet high in soy products turns out to increase the mineral content of bones, bone density can improve so that it can avoid osteoporosis problems (Rambipuji \& Jember, 2017).

In the first processing, the soybean seeds will be ground to be extracted from the juice, the starch will be used as the main ingredient in making tofu. Furthermore, soybean starch extract will be separated from most of the water which is still mixed in the starch, therefore a pressing process is needed to reduce the water content. In general, the tofu production process still uses conventional methods to press soybean starch extract, by stacking molds that produce compressive power, but the method is less efficient because the time required is relatively long and the product produced is different in results. The tofu press machine with the pneumatic system is a solution for an efficient pressing process (Wicaksana et al., 2018). By using a pneumatic system and adjustable pressure, the production time is also faster, using the same mold and pressure will produce a uniform tofu product from the texture and thickness of the tofu (Sumariyah, E.S, \& Purwanto, 2007). Sourced from pressurized air which is channeled through cubing which will move the actuator / piston which pushes the mold and presses the soybean juice into tofu.

In the West Jakarta region, there are SMEs in the culinary industry or food, namely there are the biggest centers of tofu Tempe (fermented soybean cake) producers in DKI Jakarta, as well as the national level, namely in the Semanan Kalideres area. The relocation area of the tofu Tempe production center was built on February 1992, from the relocation of producers of tofu in Tambora I, Tambora II, Kebun Jeruk, Cengkareng and Grogol.

Data from Prikompti Swakerta in 2015 stated that in Kembangan there were 2 SMEs who knew. In addition to the problems of the availability of raw materials for soybeans that must be imported, there are also problems 
with waste and several problems related to the production process, including problems related to conventional tofu press processes, so that they are less efficient, require a long time and produce non-uniform production. This is if it is not immediately addressed, it will have an economic impact.

Mercu Buana University, the Department of Mechanical Engineering, which in one of its tasks is to provide community service, can help the government to disseminate the knowledge of this automatic tofu press tool to SME Tofu to get a more efficient production process, shorter production times with uniform tofu results.

\section{METHOD}

In an effort to improve the role of higher education in the community, especially in the campus environment to the community, the University of Mercu Buana University through the Community Service Center needs to see and actively participate to help contribute directly to the community. Therefore, the research team proposed a training program for SME communities. Through socialization of the new method of tofu press automatically, the community will be given significant knowledge and skills to the needs of the individual itself in particular, and the community in the environment in general.

This socialization activity is expected to provide solutions to existing problems. By using the lecture method and practice directly about automatic tofu press tools, participants can understand in depth about how it works and how it is used. Participants can motivate and develop their potential and surrounding environment with various activities related to tofu processing.

In order to improve the efficiency of tofu processing to the community, there is a need to socialize the automatic tofu press tool to the community so that it can increase tofu production in terms of quantity and quality.

\section{Realization of Problem Solving}

In this activity, the Head of Kembangan Utara Sub-district was invited through an official letter, and then community service activities were carried out in accordance with the adjusted schedule together.

The schedule for implementing community service is carried out at:

Day, date : : Sunday, 10 March 2019

Time $\quad:$ 09:00 WIB - Finish

\section{Target Audience}

The target or target of this activity is the SME tofu community around the north Kembangan area, West Jakarta. With this activity participants are expected to gain knowledge about the new method of automatic tofu press tools.

\section{Activity Method}

The work procedures needed to support the achievement of these methods are as follows:

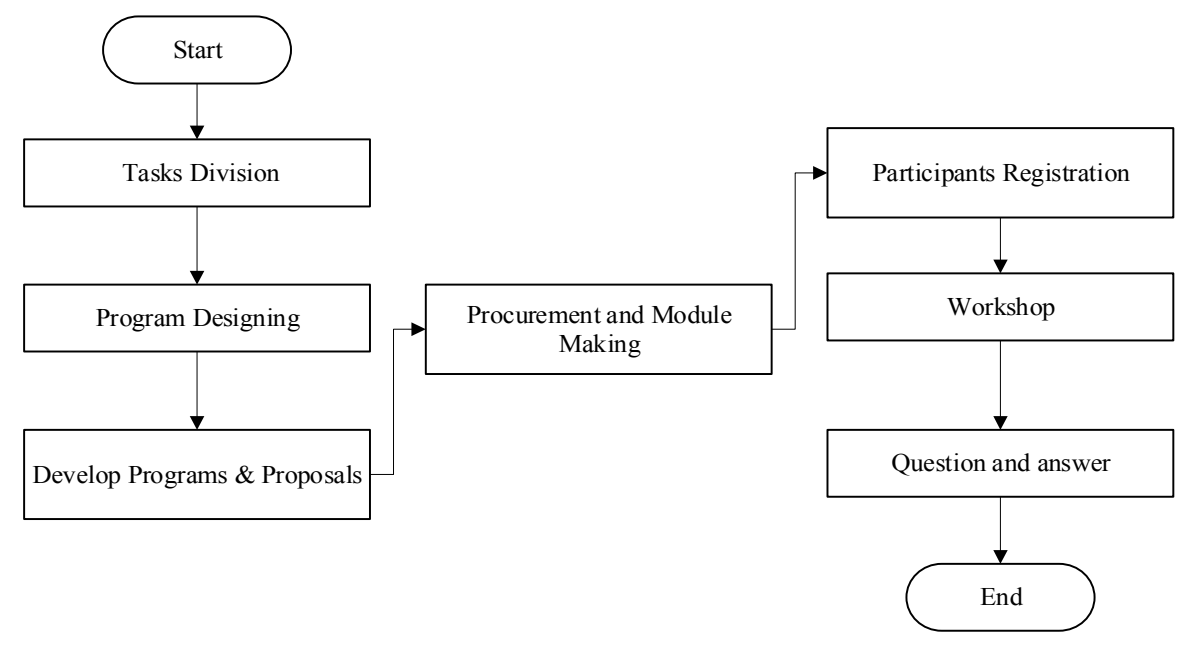

Picture 1. Flowchart Activity 
New Method Socialization The use of the Automatic Tofu Press Tool was carried out by giving explanations directly to the participants and giving questionnaires to find out the participants' responses and suggestions for this activity. The activity will be carried out in North Jakarta Kembangan North Village and the target participants are SME tofu Community. Work procedures or stages of service activities include preparation in the form of an internal team meeting and contacting the Kembangan Utara village, making modules, registering participants, implementing services and making reports.

The University of Mercu Buana University has a Research Master Plan, one of which relates to product innovation, where some of the results of the research are manifested in the form of community service carried out to provide the maximum benefit to the community. In addition to providing great benefits to the community, this service activity is also a way to promote Mercu Buana University to the community.

The method of community service activities is carried out by:

\section{Lecture}

This stage is carried out by theoretical debriefing and concepts about the activities to be carried out.

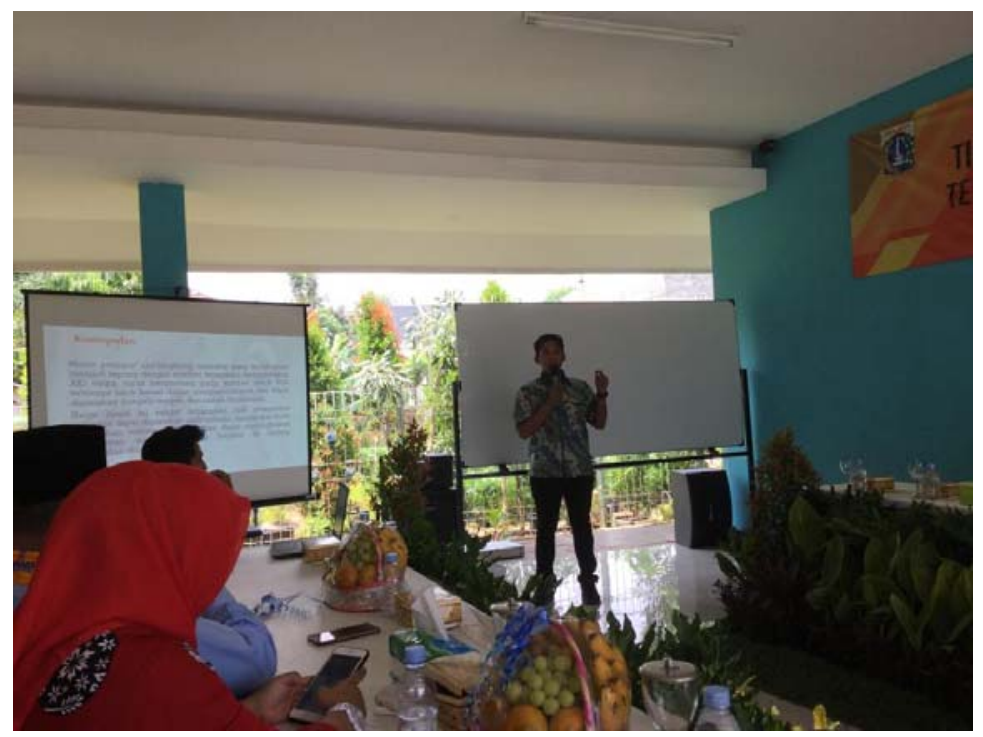

Picture 2. Lecture Method

\section{Practice}

This stage is carried out by practicing directly from the theories and concepts that were delivered in the previous session.

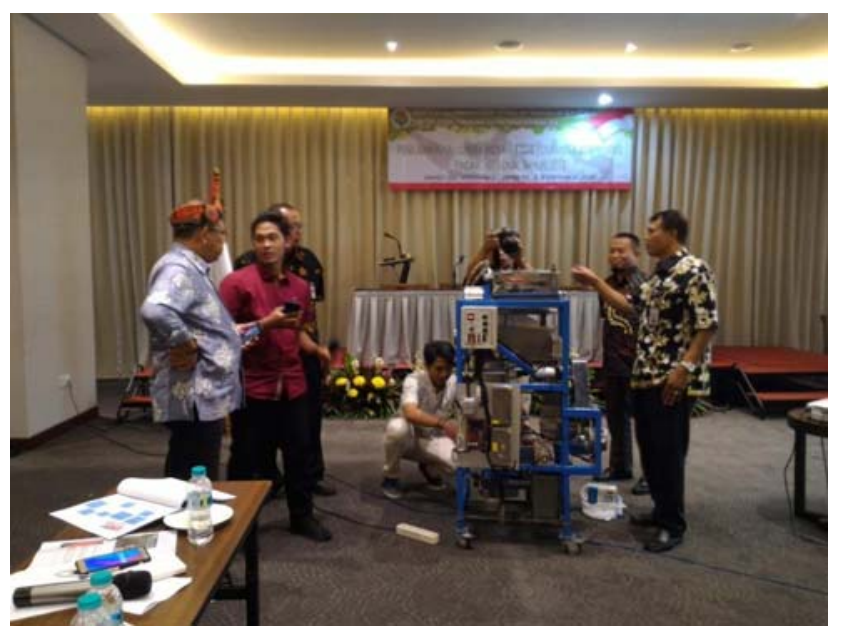

Picture 3. Practice Method 


\section{RESULTS AND DISCUSSION}

The Community Service activity was held on Sunday, March 10, 2019, located in Kembangan Utara District. Participants who attended the Community Service received training modules, lunches, and sign certificates for training. The form of training is in the form of theory and material as well as direct practice, with a weight of $30 \%$ for the provision of material, and $70 \%$ for practice.

\section{Activity Evaluation}

The evaluation of this activity is:

a. Through the attendance list, there were 25 participants out of 20 planned to attend.

b. Presentation of workshop material is carried out according to the training schedule.

c. At the time of implementation of combustion of waste using Incinerator also went smoothly

d. From the results of the workshop evaluation sheet recapitulation, it was found that the participants stated that the socialization was very useful, the participants were greatly helped by this activity to increase knowledge about press tools that could overcome the problem of tofu production.

\section{Activity Result}

Some of the results of the activities obtained in the implementation of Community Service are:

a. The participants attended the training carefully and regularly, keeping the activity environment clean.

b. The participants fully concentrate when giving training material.

c. The participants actively ask about the benefits of the automatic tofu press tool that is being delivered.

d. The participants are able to think creatively to ask other problems that can be solved by the speaker.

\section{Participant Feedback}

After the activity is completed, the training participants are asked to provide feedback or input to this training, inputs from participants include:

- Participants expect the continuity of training in the use of home industry tools, because training is very useful for solving existing problems and developing skills.

- Participants expect that in the next training, the problem resolved will intersect with new problems that have not been resolved.

\section{CONCLUSIONS AND RECOMMENDATIONS}

\section{Conclusion}

Based on the results of the implementation of the community service activities and the description of the discussion above, a number of things can be summarized as follows.

a. This extension is useful to increase public knowledge about the new method of using automatic tofu press tools.

b. Participants seemed enthusiastic and interested in this extension program.

c. Activities take place smoothly, on time and as expected.

\section{Recommendation}

a. Extension activities can be improved such as holding workshops become a medium to improve people's insight into technological developments.

b. Development of a wider extension location so that the greater the positive impact that is felt after the holding of this activity.

c. Providers of material that are more competent so that the knowledge delivered is better and develops further so that extension participants can feel the positive impact.

\section{REFERENCES}

Holle, F. R., \& Dewi, R. M. (2014). KABUPATEN SIDOARJO Fajrur Rakhman Holle dan Retno Mustika Dewi Abstrak PENDAHULUAN Industri kecil termasuk industri yang harus dikembangakan untuk meningkatkan dengan industri kecil tempe tahu maka sangat pengembangan industri kecil diperlukan karena terl. Jurnal 
https:/jurnalmahasiswa.unesa.ac.id/index.php/jupe/article/view/9313/9235

Rambipuji, K., \& Jember, K. (2017). PENGEMBANGAN INDUSTRI TAHU DAN TEMPE SEBAGAI ALTERNATIF PANGAN DI DESA CURAHMALANG KECAMATAN RAMBIPUJI KABUPATEN JEMBER Sigit Setyowibowo 1, Andri Prasetyo 2 2. PEDULI - Jurnal Ilmiah Pengabdian Pada Masyarakat, $1(2), 11-19$.

Sumariyah, E.S, J., \& Purwanto, J. (2007). Rancang Bangun Prototipe Alat Pres Tahu Otomatis Berbasis Mikrokontroler. Berkala Fisika, 10(4), 193-200.

Wicaksana, D., Poernomo, H., Fipka Bisono, D., Studi Teknik Desain dan Manufaktur, P., Teknik Permesinan Kapal, J., Perkapalan Negeri Surabaya, P., \& Studi Teknik Perpipaan, P. (2018). Rancang Bangun Mesin Pencetak Tahu Takwa Dan Stik Tahu Menggunakan Sistem Elektropneumatik. 212-218. 